\title{
ENTREPRENEURIAL CHARACTERISTICS AND PERFORMANCE OF FAMILY OWNED BUSINESS: EVIDENCE FROM WESTERN PROVINCE IN SRI LANKA
}

\author{
Arumugam Saravanabawan* \\ Department of HRM, University of Jaffna, Sri Lanka \\ sujiba2000@yahoo.co.uk \\ K. Sivanathan \\ Road Development Authority, Colombo, Sri Lanka \\ kandiahsivanathan@yahoo.com
}

\begin{abstract}
The family owned businesses are considered as common, popular business type that makes a significant contribution to the wealth of a nation in all over the world also, are important in internationalization of economies. There are ample research based evidences that the performances of the family owned businesses are better than that of non-family owned business. The inherent characteristics of family owned businesses may determine the higher performances. Therefore, the proposed research attempts to investigate the determinants of the performances of family owned business in Sri Lankan Context. Data were collected directly form owner managers of family owned businesses in Western Province, Sri Lanka. The findings of the study help to identify the Entrepreneurial characteristics and family owned business performances, and provide insight to lead such businesses to success. The study focuses on three entrepreneurial characteristics: planning, achievement and power competency. The findings establish a significant impact of planning competency of entrepreneurs on family owned business performances. On the basis of these findings, managerial implications of this study and future research direction were highlighted.
\end{abstract}

Keywords: Family owned business; Entrepreneurship; Planning competency; Achievement Competency; Power competency 


\section{Introduction}

In most countries of the world, the role of Family Owned Businesses has remained noteworthy throughout the 20th century. The importance of the Family Businesses also seems to have been increasing over time. The family owned businesses are considered as common, popular business type that makes a significant contribution to the wealth of a nation in all over the world with a proportion of $80-95 \%$ of businesses and interestingly their performances are better compared to non-family owned businesses (Nordqvist \& Melin, 2010; Abdellatif et al., 2010; Alpay et al., 2008). The connection between entrepreneurship and family business is widely unrecognized. Families are vital and supportive environments for entrepreneurial behavior. Entrepreneurship research has revealed that family support and the presence of selfemployed parents are important influences in venture initiation and business ownership (Shapero and Sokol, 1982; Cooper, 1986). Entrepreneurship is the start and heart of most family businesses and the phenomenon of an entrepreneurial family fosters, subsidizes who engage in entrepreneurship. In fact, the family business is quite simply the "wider-lens" view of entrepreneurship as the initial business efforts of one or more family members grow and change over time. In the present literature, it is seen that there is lack of empirical research on the relationship between entrepreneurial characteristics and the business performance of family owned business in Sri Lanka. Given the lack of academic research about this topic, the objective of this study is to examine the entrepreneurial characteristics and the business performance of family owned business.

Further, according to the Kuznetsov, McDonald and Kuznetsova (2000) although a successful entrepreneur should possess all of these competencies, their relative importance varies according to the environment in which the business operates. The findings and theories related to entrepreneurial characteristics are from Western context, reflecting such individualist cultural contexts and thus, the findings of such studies cannot be generalized to nations like Sri Lanka with diverse cultures. Notably, studies on entrepreneurial characteristics have been far less focused on Asian contexts where collectivist culture is more prevalent. Therefore the research problem which focused here is "What extent entrepreneurial characteristics influence the performance of family owned business in Sri Lankan context?" Thus, this study explores whether the entrepreneurial characteristics of family owned businesses determine the higher performances in such context. 


\section{Significance of the Study}

Performance of the business depends on various factors such as the competencies of the entrepreneurs, values, expectations, and management practices. Even though all these factors contribute to the performance of the business, present study considers the entrepreneurial competencies as the key factor in determining the performance of family owned business. Even though other factors may determine the performance of the business in different angle, the entrepreneurial competencies are the only factors which coordinate other factors towards the performance of the family owned business. Skills and competencies have taken much concern of researchers at past and present in view of success of entrepreneurs. According to Kuznetsov, McDonald and Kuznetsova (2000) entrepreneurial competencies and their interaction with strategy and industry structure have become increasingly looked upon as principal factors determining the success of new ventures. Thus, the finding of the present study helps the entrepreneurs / owner managers to understand how their entrepreneurial competencies determine the performance of the family owned business. The business performance is crucial in the determining the survival of the business. The present study can be considered as an attempt to open doors to evaluate entrepreneurial characteristics to achieve the business success.

\section{Theoretical Background and Hypotheses}

\subsection{Familyowned business}

Although many small and micro businesses are family owned and operated, there is evidence that family firms are also fast growth firms and very large successful firms. Broadly, family business has been defined as a business that is owned and managed (i.e. controlled) by one or more family members (Handler, 1989; Hollander \& Elman, 1988). A more detailed definition is provided by Davis and Tagiuri (1982). They define family firms as "---- organizations where two or more extended family members influence the direction of the business through the exercise of kinship ties, management roles, or ownership rights." Moreover, Gallo (1994) has asserted that family businesses are essentially the same in every country in the world relative to their problems, issues, and interests.

\subsection{Entrepreneurial competencies}

The unique characteristics of entrepreneurs were occasionally the topic of research in the social sciences field. Entrepreneur characteristics are unique and different from 
non entrepreneurs (McClelland, 1961; Brockhaus, 1980; Schere 1982; Law \& MacMillan, 1988). An extensive research conducted worldwide by the management system international (MSI) team has pointed out ten key personal entrepreneurial characteristics that separate successful from unsuccessful businesses. These characteristics are divided into three major categories: achievement competencies, planning competencies, power competencies. These competencies have been dealt with many researchers under various contexts. Also, researchers have noted the necessity of these competencies for business success. A competency can be considered as a kind of higher level characteristic, encompassing different personality traits, skills and knowledge, which are in turn influenced by the entrepreneur's experience, training, education, family background and other demographic variables (Bird, 1995). The characteristics of entrepreneurs have been studied from a variety of perspectives and by a variety of needs i.e., Need for Achievement; Need for Power; Need for Affiliation (McClelland, 1961). This study focuses on three competencies (achievement, planning and power) that are required for the family owned business success.

A competency can be considered as kind of higher level characteristic, encompassing different personality traits, skills and knowledge, which are in turn influenced by the entrepreneur's experience, training, education, family background and other demographic variables (Birs, 1995).

A critical review of literature on competencies done by Man, Lau and Chan (2002) identifies six entrepreneurial competency areas from a process perspective. This includes opportunity competencies, relationship competencies, conceptual competencies, organizing competencies, strategic competencies and commitment competencies.

Overall, previous research provides several ideas on the set of competencies needed for small business success. The findings were similar in some cases and the competencies were named differently and which overlaps in many cases. Some of them (Hornaday and Aboud, 1971; Durand, 1974; Kuznetsov, McDonald and Kuznetsova, 2000) have taken the personal characteristics as the core competencies and others (Man and Lau, 2000; Man, Lau and Chan, 2002; Huck and McEwen, 1991; Gaskill, Van Auken and Manning, 1993) have taken a different stand in identifying 
competencies with functional bases of business operations. As Kuznetsov, McDonald and Kuznetsova (2000) suggests, although a successful entrepreneur should possess all of these competencies, their relative importance varies according to the environment in which the business operates.

\subsection{Achievementcompetencies}

Individuals with high need for achievement are dominated by a desire to influence and control the context in which they operate since they seems to be ambitious, hard working, competitive, keen to improve their social standing, and they place high value on achievements (McClelland, 1961, Papadakis, 2006). Previous studies on entrepreneurial aspects pointed out that a significant psychological explanation of entrepreneurial acts is the need for achievement (Shapero \& Sokol, 1982; Brockhaus, 1980). Researchers found empirical support that the entrepreneurs are initially driven by 'push' factors and have the achievement motivation. From his/her prospective, the main characteristic of the business initiators is the higher need for achievement described as a preference for challenge, acceptance of personal responsibility for outcomes and innovativeness (Ivanova \& Gibcus, 2003).

\subsection{Planning competencies}

Durand (1974), through his research with a practical orientation, found that an entrepreneur must have the necessary skills to transform his desires and hopes into overt actions. Many researchers; Timmons, 1979; Gaskill et al., 1993; Monk, 2000) confirms that poor management was often a reason for failure of enterprises, and suggests that business planning is important for business success.

\subsection{Power competencies}

Power competencies of an entrepreneur consists persuasion and networking, Self confidence and correcting factors (responsiveness to criticism and suggestions, ability to learn from mistakes). The need for power is essential to have control over others, to influence their behavior. Man and Lau (2000) identified competency areas such as opportunity competencies, relationship competencies, conceptual competencies, organizing competencies, strategic competencies, commitment competencies, and supporting competencies. A critical review of literature on competencies done by Man et al. (2002) identified six entrepreneurial competency areas from a process perspective. They are: opportunity competencies, relationship competencies, 
conceptual competencies, organizing competencies, strategic competencies and commitment competencies.

\subsection{Entrepreneurial characteristics and family owned business performance}

Broadly, family business has been defined as a business that is owned and managed (i.e. controlled) by one or more family members (Handler, 1989; Hollander \& Elman, 1988). Ibrahim and Goodwin (1986) stated that "success in business is defined in terms of rate of return on sales and age of longevity of the firm". Cuba et al. (1983) and Khan and Rocha (1982) also found that sales, profit and longevity were important to business success.

Small business success, indeed all business success is predominantly measured in either increases in turnover, or revenue or increase in number of people employed (Barkham et al. 1996; Bruderl \& Preisendorfer, 1998; Gibb \& Davies, 1990; Holmes \& Zimmer, 1994; Ibrahim \& Goodwin, 1986; Kalleberg \& Leicht, 1991). Many previous studies (Bamberger, 1983; Porter, 1985; Covin and Slevin, 1989; Kotey and Meredith 1997; Kuznetsov et al., 2000) found relationship between entrepreneurial characteristics and business performance. In the literature review, it is noticed that the characteristics of entrepreneurs influence the family owned business performance. Accordingly, the following hypotheses are developed for the purpose of this study.

$H_{1}$ : There is a positive relationship between planning competencies and family owned business performance.

$\mathrm{H}_{2}$ : Planing competency tends to have higher impact than achievement competency and power competency on family owned business performance.

$H_{3}$ : Family owned businesses headed by entrepreneurs having higher planning competency tend to have higher business performance than those entrepreneurs do not have higher planning competency.

$H_{4}$ : Family owned businesses headed by male entrepreneurs who possess higher planning competency tend to have higher business performance than female entrepreneurs.

$H_{5}:$ Family owned businesses headed by entrepreneurs having more experience tend to have higher business performance than those who having less experience. 


\section{Methodology}

\subsection{Conceptualmodel}

Proposed conceptual model of the study, including the dependent and independent variables is described in the Figure 1. It includes three independent variables (achievement, planning and power competency). The dependent variable is the performance of family owned business.

Independent variables

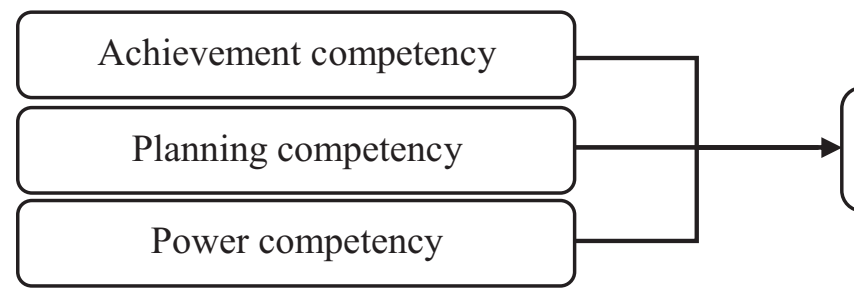

Dependent variable

Family Owned Business

Performance

\section{Figure 1: Conceptual Model}

\subsection{Source of data and sample procedure}

Data were gathered through a questionnaire distributed among the owner/manager of family owned Businesses Western Province of Sri Lanka. The level of competition and potential market opportunity are high compare to other provinces. Thus, researchers focused mainly on western province to collect the data to capture the potential competencies of entrepreneurs. A randomly selected sample of 75 owner managers of family owned business were considered for the data collection. Finally, 50 completed questionnaires were used in data analysis.

\subsection{Measures and questionnaire}

The questionnaire divided into 3 parts. The Part $\mathrm{A}$ focused on demographic and organizational characteristics. Part B and C consist series of questions to elicit information about the entrepreneurial characteristics and business performance respectively, using 5 point likert scale ranging from strongly agree to strongly disagree.

\subsection{Entrepreneurial competencies scale}

Entrepreneurial competencies scale consists three major parts; achievement competency, planning competency, and power competency. These competencies were

\begin{tabular}{lll}
\hline Journal of Business Studies, 7(1) & $-116-$ & 2020
\end{tabular}


measured using a five point likert scale ranging from 1(Strongly disagree) to 5(strongly agree). Achievement competency scale includes 25 items to measure entrepreneurs' achievement competency. The sample items were "you search for new aspects to do", "you take repeated attempts to gather appropriate persons to achieve your goal". The achievement competency has a high level reliability with Cronbach's Alpha 0.76. Planning competency scale includes 15 items to measure entrepreneurs' planning competency. The sample items were "You like to think and plan about the future", "you search for lot of information before starting a new work". Planning competency has a high level reliability with Cronbach's Alpha 0.80. Power competency scale includes 15 items to measure entrepreneurial planning competency. The sample items were; "you get others to work for your recommendations", "you have the confidence of winning, whatever task". Power competency has a high level reliability with Cronbach's Alpha 0.74

\subsection{Business performance scale}

Entrepreneurs were asked serious of questions regarding their business performance by using five point Likert scale ranging from 1(Strongly disagree) to 5(strongly agree). Six items were included to measure the business performance. Sample items "Number of employees or personal increased", "amount in turnover increased", "profit in business increased". Business performance has a high level reliability with Cronbach's Alpha 0.92.

\subsection{Dataanalysis}

Data analysis carried out in two steps. The first step presents the background information of the research sample, and the second step tests the relationships conceptualized in the study. Data analyzed with correlation, and multiple regressions to find out the relationship between the entrepreneurial, demographic characteristics and business performance of family owned Business. 


\section{Results}

Table 1: Correlation between Business Performance and Planning Competency

\begin{tabular}{llc}
\hline \hline & $\begin{array}{l}\text { Business } \\
\text { Performance }\end{array}$ & Planning Competency \\
\hline \hline Business performance & 1.0000 & \\
Planning competency & 0.5334 & 1.0000 \\
& 0.0001 & \\
\hline \hline
\end{tabular}

The analysis reveals that there is a positive relationship between planning competencies and family owned business performance $(\mathrm{r}=.53, \mathrm{p}<0001)$. Hypothesis 1 posits that planning competencies of the entrepreneurs increase the family owned business performance. As predicted, the coefficient for that interaction is positive and significant, supporting hypothesis 1 . The magnitude of the hypothesized effects is considerable.

Hypothesis 2 posits that planning competency tends to have higher impact than achievement competency and power competency on family owned business performance. Therefore, the model 1 considered achievement, planning and power competency as independent variables. As depicted in the model 1 in Table 2, the results indicate that planning competency has higher impact than achievement and power competency. The coefficient of determination of model 1 indicates that above 30 percent of the variation of business performances can be explained by the independent variables.

The model 2 in the Table 2 developed for the hypothesis 3 . It posits that entrepreneurs of family owned businesses having higher planning competency tend to have higher business performance than those entrepreneurs do not have higher planning competency. The results indicate that higher planning competency effect on business performances of family owned businesses $(\beta=0.77, p<0.01)$. In this model, 20 percent of the variation of business performance can be explained by higher planning competency. 
Table 2: Coefficients from OLS Regression of Business Performance on Selected Independent Variables

\begin{tabular}{|c|c|c|c|c|}
\hline & Model 1 & Model 2 & Model 3 & Model 4 \\
\hline Achievement & $\begin{array}{l}-0.23 \\
(0.36)\end{array}$ & & & \\
\hline Planning & $\begin{array}{l}0.77 * * * \\
(0.25)\end{array}$ & & & \\
\hline Power & $\begin{array}{l}0.31 \\
(0.29)\end{array}$ & & & \\
\hline Higher Planning & & $\begin{array}{l}0.77 * * * \\
(0.22)\end{array}$ & $\begin{array}{l}0.08 \\
(0.47)\end{array}$ & \\
\hline Male & & & $\begin{array}{l}1.20 * * * \\
(0.28)\end{array}$ & \\
\hline Higher Planning_1 X male_1 & & & $\begin{array}{l}0.24 \\
(0.52)\end{array}$ & \\
\hline Higher Experience1 & & & & $\begin{array}{l}0.06 \\
(0.25)\end{array}$ \\
\hline Constant & $\begin{array}{l}-0.41 \\
(0.91) \\
\end{array}$ & $\begin{array}{l}2.33 * * * \\
(0.17)\end{array}$ & $\begin{array}{l}1.67 * * * \\
(0.21)\end{array}$ & $\begin{array}{l}2.80 * * * \\
(0.14)\end{array}$ \\
\hline R-squared & 0.30 & 0.20 & 0.51 & 0.00 \\
\hline Adjusted R-squared & 0.26 & 0.19 & 0.48 & -0.02 \\
\hline $\mathrm{N}$ & 50 & 50 & 50 & 50 \\
\hline
\end{tabular}

The model 3 in the Table 2 is developed for the hypothesis 4 . It was hypothesised that family owned businesses headed by male entrepreneurs who possess higher planning competency tend to have higher business performance than female entrepreneurs. The results do not provide sufficient evidences that family owned businesses headed by male entrepreneurs who possess higher planning competency tend to have higher business performance than female entrepreneurs $(\beta=0.24, \mathrm{p}>0.1)$. The coefficient of determinants of model 3 indicates $51 \%$ of the variation is determined by the independent variables.

The hypothesis 5 posits that the family owned businesses having more experience tend to have higher business performance than those who having less experience. The model 4 in the Table 2 developed for the hypothesis 5 . The results of the regression 
analysis indicated that there is positive and weak impact on business performance by number of years of experience. Therefore, the magnitude of the hypothesized effect is not noteworthy.

Table 3: Coefficients from OLS Regression of Business performance on Selected Independent Variables

\begin{tabular}{llll}
\hline & Model 1 & Model 2 & Model 3 \\
\hline Planning & $0.79^{* * *}$ & $0.69^{* * *}$ & $0.80^{* * *}$ \\
& $(0.18)$ & $(0.22)$ & $(0.25)$ \\
Power & & 0.21 & \\
Achievement & & $(0.24)$ & -0.02 \\
& & & $(0.30)$ \\
Constant & -0.22 & -0.62 & -0.18 \\
& $(0.70)$ & $(0.84)$ & $(0.88)$ \\
\hline R-squared & 0.28 & 0.30 & 0.28 \\
Adjusted R-squared & 0.27 & 0.27 & 0.25 \\
$\mathrm{~N}$ & 50 & 50 & 50 \\
\hline$* \mathrm{p}<0.1, * * \mathrm{p}<0.05, * * * \mathrm{p}<0.01$ & &
\end{tabular}

The Table 3 includes further analysis on the three competencies considered in the conceptual model. The model 1 in the Table 3 considers the impact of planning competency on business performance of family owned businesses. The model 2 in Table 3 considered the impact of both planning and power competency on business performance. And, the model 3 considers the impact of both planning and achievement competency on business performance. The three models indicates significant results $(\mathrm{p}<0.01)$. It is noticed that the coefficient of determination of model 1 is $(\mathrm{R} 2=0.28) 28$ percent. Therefore, 28 percent of the variance in the performance is explained by the planning competency. Once the power competency is added to the model 2 , it indicates higher coefficient of determination $(\mathrm{R} 2=.30)$ and it indicates that there is an impact of power competency towards business performances. However, after adding achievement competency to the model 3 , there is no any change in coefficient of determinant. 


\section{Discussion}

The findings of this research consistent with previous studies (Gartner, 1985; Sandberg \& Hofer, 1987; Kotey \& Meredith, 1997) that entrepreneurial characteristics typically produce the relationship with business performance. Empirical findings of this study do not strongly support the theoretical perspective, and indicate mixed-results that there is relationship between entrepreneurial characteristics and business performances. When the independent variables are concern, the empirical findings establish a relationship between the planning competency and business performances. The analysis show that a significant relationship between planning competency and business performances. It supports the present theoretical background. Even though, the power competency has some effect towards the business performance, achievement competency does not. And also, it is clear that the planning competency has higher impact on business performances than power and achievement competency. Therefore, the study makes significant contribution to the present literature that planning competency is salient in family owned business performance, also it is important than power and achievement competency.

Since the planning competency is having the significant impact on the performances of family owned businesses, it is vital to investigate whether having higher planning competency has greater impact on business performances than not having the same. Those entrepreneurs having higher planning competency has greater impact towards the higher performance. Present theories also confirm these empirical findings. Therefore, entrepreneurs of family businesses need to have higher planning competency for higher business performances.

Family owned businesses are run by both females and males. Since it has already been seen that the planning competency is crucial in family owned business performance, it is vital to broaden the study to the gender. As literature suggests, there are empirical evidences that the gender has higher impact on business performance. Particularly male entrepreneurs have higher and significant impact towards the business performance. We do not have sufficient evidences to say family owned businesses headed by male entrepreneurs who possess higher planning competency have higher business performance than female entrepreneurs. Thus, this study provides a notable contribution that effect of planning competency on business performances of family 
owned businesses does not vary among gender. Finally, the research attempted to establish a relationship between experiences of family owned businesses and business performances. However, there are no sufficient evidences to say that such relationship exists in family owned businesses.

\section{Implication And Conclusion}

There are ample research based evidences that entrepreneurial characteristics had greater influence on business performances, and family owned businesses has higher business performances than non-family owned businesses. The study begins with the question that what entrepreneurial characteristics contribute to the family owned business success. The study considered three entrepreneurial competencies: planning, achievement and power competencies. A sample of 50 family business owners was selected on random basis in Colombo district Western Province of Sri Lanka for the study.

The study found that planning competency has higher and significant effect on family business performances. The power competency has greater impact towards the family business performances than achievement competency. Further, the study concluded that family owned businesses having higher planning competency have higher business performance than those entrepreneurs who do not have higher planning competency. However, effect of planning competency on business performances of family owned businesses does not vary among gender. Also, experience of family owned businesses has no effect on performance of family owned businesses. As a whole, this study emphasizes the importance of planning competency with aim of reaching higher performances of family owned businesses. The family owned businesses therefore, concentrate heavily on planning competency. Finally, in this research we found that planning competency impacts on family owned business performances. However, there may be other determinants that contribute to the higher performance of family owned businesses than non-family owned businesses. Therefore, there is a great potential for researches to investigate those determinants. Further, this study mainly focused in the Western Province in Sri Lanka. To get more generalizable findings in Sri Lankan context, where, Sri Lankans are said to be collectivists, data should be collected considering other provinces. 


\section{References:}

Abdellatif, Mahamat., Amann, Bruno. \& Jaussaud, Jacques. (2010) Family versus nonfamily business: A comparison of international strategies. Journal of Family Business Strategy 1 pp.108-116

Alpay G, Bodur M, Yılmaz C, Çetinkaya S, \& Arikan L (2008) Performance implications of institutionalization process in family owned businesses: Evidence from an emerging economy. J. World Bus., 43: pp.435-448.

Bamberger, I. (1983). Value systems, strategies and performance in small and medium sized firms. International Small Business Journal 1 (4), pp.25-39.

Barkham, R., Gudgin, G., Hart, M. and \& Hanvey, E. (1996) The Determinants of Small Firm Growth. London: Jessica Kingsley.

Bird, B. (1995). Toward a Theory of Entrepreneurial Competency. .In J.A.Katz \& R.H.Brockhaus, Sr.(Eds), Advances in Entrepreneurship, Firm Emergence, and Growth. 2,51-72. Greenwich, CN: JAI Press

Bird, B. (1995). Toward a theory of entrepreneurial competency. Advances in Entrepreneurship, Firm Emergence, and Growth, JAI Press, p.2, pp.51-72.

Brockhaus, R.( 1980) Risk Taking Propensity of Entrepreneurs, The Academy of Management Journal; 23(3): 509-520.

Bruderl, J. \& Preisendorfer, P. (1998) "Network Support and Success of Newly Founded Businesses". Small Business Economics, 10, pp. 213-225.

Cooper, A. (1986), Entrepreneurship and High Technology. In D.Sexton and R.Smilor (Eds.), The Art and Science of Entrepreneurship, Cambridge: Ballanger Publishing Company, pp.153-168.

Covin, J. G., \& Slevin, D. P. (1989). Strategic management of small firms in hostile and benign environments. Strategic Management Journal, 10: 75-87.

Cuba, R., D. DeCenzo, \& A. Anish (1983). Management Practices of Successful Female Business Owners, American Journal of Small Business vol. 8, no. 2, pp. 40-45.

Davis, J.A., \& Tagiuri, R., (1982). Bivalent Attributes of the Family Firm, Santa Barbara, CA: Owner managed Business Institute. 
Durand, Douglas E. (1974) Training and Development of Entrepreneurs: A Comparison of Motivation and Skill Approaches, Journal of Small Business Management, Vol.12 Issue 4, pp.23-26.

Gallo, M.A. (1994). Global Perspectives on Family Businesses, Chicago: Loyola University, Family Business Center.

Gartner, W.B. (1985). A framework for describing the phenomenon of new venture creation. Academy of Management review, 10, 696-706.

Gaskill, Lu Ann Ricketts., Van Auken, Howard E. \& Manning, Ronald A. (1993) A Factor Analytic Study of The Perceived Causes of Small Business Failure, Journal of Small Business Management, Vol. 31 Issue 4, pp18-31

Gibb, A.A. \& Davies, L.G. (1990), 'In pursuit of frameworks for the development of growth models of the small business', International Small Business Journal, vol. 9, no. 1,pp. 15-31.

Handler, W.C. (1989), Methodological Issues and Considerations in Studying Family Businesses, Family Business Review, 2, pp.257-276.

Hollander, B.S., and Elman, N.S., (1988). Family-owned Businesses: An Emerging Field of Inquiry, Family Business Review, 1, pp.145-164.

Hornaday, John A. and Aboud, John, (1971) Characteristics of Successful Entrepreneurs, Personnel Psychology, 24, pp.141-153.

Huck, John F. and McEwen, Thaddeus. (1991) Competencies Needed For Small Business Success: Perceptions of Jamaican Entrepreneurs, Journal of Small Business Management, Oct91, Vol. 29 Issue 4, pp.90-93

Holmes, S. \& Zimmer, I. (1994), 'The nature of the small firm: understanding the motivations of growth and non-growth oriented owners', Australian Journal of Management, vol. 19, no. 1, pp. 97-120:

Ibrahim, A. B. and J. R. Goodwin (1986), Perceived Causes of Success in Small Business. American Journal of Small Business 11(2), pp.41-50.

Ivanova E., Gibcus P. (2003)The decision making entrepreneur. Literature overview. SCALES-paper N200219. EIM Business \& Policy research,. Zoetermeer,

Kalleberg, A.L., and Leicht, T.K. (1991). Gender and Organizational Performance: Determinants of Small Business Survival and Success, Academy of Management Journal, 34(1), pp.136-161. 
Khan, R. \& Rocha, J. (1982), Recurring managerial problems in small business. American Journal of Small Business, 7(1), pp.50-58.

Kotey, B and Meredith, G,G (1997); relationship among owner manager personal values, Business strategy and enterprise performance. Journal of small business management, pp.37-64.

Kuznetsov, A., McDonald, F., and Kuznetsova, O., (2000) Entrepreneurial Qualities: A Case from Russia, Journal of Small Business Management, Vol.38, Issue.1, pp.101-107.

Law, M.B., and MacMillan, I.C. (1988) Entrepreneurship: Past Research and Future Challenges Journal of Management 14: pp.139-161,

Man, T.W.Y., and Lau, T. (2000) Entrepreneurial Competencies of SME Owner/Managers in The Hong Kong Services Sector: A Qualitative analysis, Journal of Enterprising Culture, Vol.8, No.3, , pp.235-254.

Man, T.W.Y., Lau, T., and Chan, K.F. (2002). The competitiveness of small and medium enterprises: A conceptualization with focus on entrepreneurial competencies, Journal of Small Business Venturing 17, pp.123-142.

McClelland D. C., (1961), The Achieving Society, New York, van Nostrand.

Monk, R. (2000) Why Small Businesses Fail, CMA Management, Vol.74, Issue 6, pp.12-13

Nordqvist, M. \& Melin, L. (2010), Entrepreneurial Families and Family Firms, Entrepreneurship \& Regional Development, 22 (3): 1-29

Papadakis, V. M. (2006). Do CEOs Shape the Process of Making Strategic Decisions? Evidence from Greece, Management Decision, 44(3): pp.367-394.

Porter, M.E. (1985) Competitive Advantage. Creating and Sustaining Superior Performance, The Free Press, and New York.

Sandberg, W. R., \& Hofer, C. W., (1987) Improving New Venture Performance: The Role of Strategy, Industry Structure, and the Entrepreneur. Entrepreneurship Theory and Practice, Vol.16, pp.73-90. 
Schere, J. (1982) Tolerance and Ambiguity as a Discriminating Variable between Entrepreneurs and Managers, Proceeding of The Academy of Management Conference, New York, pp.404-408.

Shapero, A., and Sokol, L., (1982) 'The Social Dimensions of Entrepreneurship', in C. Kent, D. Sexton, and K. H. Vesper (eds.) The Encyclopedia of Entrepreneurship. Englewood Cliffs, NJ: Prentice-Hall. 72-90.

Timmons, J. A. (1979) Careful Self-Analysis and Team Assessment Can Aid Entrepreneurs, in Gumpert, David E. (ed.) Growing Concerns: Tools for evaluating the start-up venture and for financing the existing one, Harvard Business Review, pp.198-206. 